\title{
PROJECT EDUCATION AND ITS ASPECTS FOR PUPIL'S CREATIVITY IN TEACHING PROCESS
}

\author{
Jaroslav ZUKERSTEIN
}

\section{PROJEKTOVÁ VÝUKA A ASPEKTY TVOŘIVOSTI V EDUKAČNÍM PROCESU}

(NOVOTNÝ, J. Projektová výuka a aspekty tvořivosti v edukačním procesu. 1. vydání. Ústí nad Labem: Univerzita J. E. Purkyně, 2012. 116 s. ISBN 978-80-7414-431-8).

Univerzita Jana Evangelisty Purkyně v Ústí nad Labem vydala $\mathrm{V}$ roce 2012 publikaci Projektová výuka a aspekty tvořivosti v edukačním procesu autora PhDr. Jana Novotného Ph.D. Uvedená monografie je vydána v souvislosti s projektem „To je věda, seznamte $\mathrm{se}^{\text {“ }}$ podpora systematické práce s žáky a studenty $\mathrm{v}$ oblasti vědy, výzkumu a vývoje CZ.1.07/2.3.00/09.0121, který je spolufinancován Evropským sociálním fondem a státním rozpočtem České republiky.

UNIVERZITA J. E. PURKYNE V USTI NAD LABEM
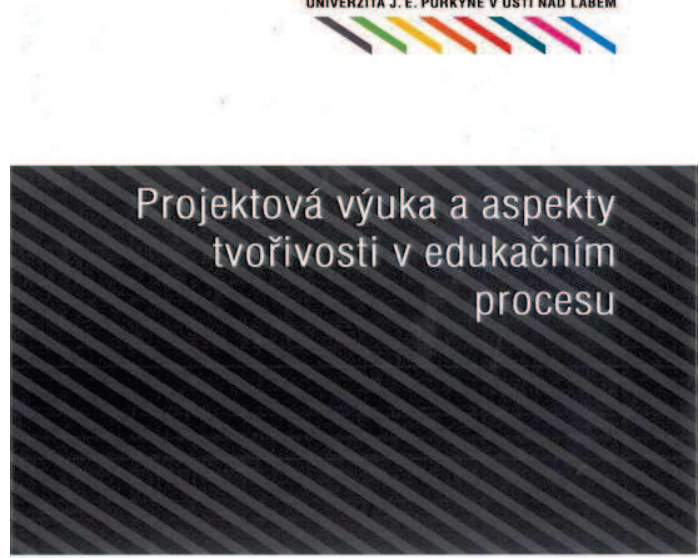

Jan Novotný

Autor publikace „Projektová výuka a aspekty tvořivosti v edukačním procesu“ se ve své práci zabývá možnostmi využití projektových metod a jejich vlivu na úroveň osvojení technicky orientovaného učiva, na žákovskou oblibu technických a př́rodovědeckých předmětů a na možnosti zvýšení úrovně technické tvořivosti žáků základních škol.

Monografie je rozdělena do dvou základních částí. V první části, která se skládá ze čtyř kapitol, autor definuje základní pojmy a východiska současného školského systému a výuky prostřednictvím projektových a problémových metod. Autor zařadil do první části monografie také kapitolu porovnávající projektovou výuku u nás a v zahraničí. Čtvrtou kapitolu autor věnuje problematice tvořivého vyučování, včetně možností rozvoje tvořivosti žáků.

Druhá část monografie je věnována pedagogickému výzkumu, jehož hlavními oblastmi pozornosti jsou: Efektivita získávání poznatků a jejich trvalost při využívání projektových a problémových metod, oblíbenost vyučovacího předmětu u žáků ve vztahu k zařazování projektových a problémových metod a zvyšování úrovně technické tvořivosti působením projektových a problémových metod.

Jedná se o poměrně obsáhlý a precizně zpracovaný výzkum experimentálně ověřující dané cíle. Výzkum je podpořen vhodnými nástroji a podklady experimentu. Každá z ověřovaných hypotéz je dopodrobna podložena daty získanými na základech experimentálních šetření. Autor sesbíraná data a podklady výzkumu fundovaně zpracoval a statisticky vyhodnotil.

Celá publikace působí uceleným dojmem, přináší současný pohled na problematiku projektových metod a tvořivosti. Dá se tedy konstatovat, že je vhodné ji doporučit jako materiál pro odbornou pedagogickou veřejnost, ale naprríklad i pro studenty pedagogických fakult.

PhDr. Jaroslav Zukerstein, Ph.D.

Katedra energetiky a elektrotechniky

Fakulta výrobních technologií a managementu

Univerzity J. E. Purkyně

Na Okraji 1001, Ústí nad Labem, ČR

Tel: +420 475285511

E-mail: zukerstein@fvtm.ujep.cz

Www pracoviště: www.fvtm.ujep.cz 